Weronika Wojtanowska weronikamw@vp.p1 https://orcid.org/0000-0003-3727-0517

Uniwersytet Papieski Jana Pawła II w Krakowie

\title{
O możliwości zastosowania Nagelowskiej typologii racji do działania we współczesnej etyce cnót
}

\section{Wstęp}

Celem artykułu jest przedstawienie możliwości powiązania współczesnej, neoarystotelesowskiej etyki cnót z problematyką dotyczącą typologii racji do działania ${ }^{1}$. Pozwoliłoby to w większym stopniu zbliżyć ją do modelu niedyrektywnego, dzięki czemu zmniejszyłaby się adekwatność obiekcji, które są wysuwane wobec etyki cnót przez jej przeciwników. Jednocześnie zaproponowane ujęcie mogłoby w pewnym stopniu przyczynić się do udoskonalenia współczesnej etyki cnót oraz wzmocnienia jej zdolności do stawiania czoła wyzwaniom i problemom współczesnego świata.

Ze względu na ograniczone ramy artykułu głównym punktem odniesienia w części polemicznej będą rozważania Nataszy Szutty mające na celu odparcie zarzutów wobec etyki cnót oraz jej argumentacja dotycząca przewagi edukacji moralnej opartej na kategorii cnoty nad modelem niedyrektywnym. W pozytywnej części artykułu nawiążę do współczesnych koncepcji próbujących połączyć etykę cnót z filozofią moralną opartą na pojęciu racji. Podejmę próbę wykazania, że typologia racji do działania, która została zaproponowana przez Thomasa Nagela, może zostać powiązana z praktycznym wymiarem kształtowania cnót w procesie wychowania, co z kolei może przyczynić się do większego zbliżenia etyki cnót do modelu niedyrektywnego.

\footnotetext{
${ }^{1}$ Artykuł powstał w ramach projektu badawczego nr 2016/23/N/HS1/00641, finansowanego przez Narodowe Centrum Nauki.
} 


\section{Problemy współczesnej etyki cnót}

Neoarystotelesowska etyka cnót zyskuje coraz większą popularność i znaczenie, również na gruncie filozofii polskiej². Jednocześnie, wraz ze wzrostem zainteresowania rośnie liczba publikacji krytycznych wobec tego nurtu. Zarzuty wysuwane są ze strony różnorodnych stanowisk i dotyczą różnych poziomów refleksji. Na podstawie badań eksperymentalnych poddaje się w wątpliwość nie tylko możliwość kształtowania, ale nawet samo istnienie tak fundamentalnych kategorii, jak charakter i cnota w ich tradycyjnym rozumieniu. Krytyka etyki cnót ma miejsce również na płaszczyźnie etycznej i zarazem praktycznej, ponieważ analiza psychologicznych mechanizmów związanych z procesem wychowania i edukacji moralnej może prowadzić do prób podważenia godziwości i akceptowalności metod, którymi posługują się wychowawcy zajmujący się praktycznym wdrażaniem cnót.

Zarzuty pierwszego typu, dotyczące efektywności etyki cnót, wysuwane są przede wszystkim ze strony sytuacjonistów, którzy zaprzeczają istnieniu elementów niezbędnych do tego, aby można było zasadnie mówić o istnieniu charakteru. Istotą argumentacji jest powoływanie się na wyniki badań empirycznych, które wykazują, że na podejmowane decyzje przemożny wpływ mają czynniki sytuacyjne, zarówno o charakterze zewnętrznym, jak i wewnętrznym. W związku z tym w wątpliwość poddawana jest efektywność działań mających na celu udoskonalenie charakteru człowieka, jako że jego decyzje zdają się wynikać w znacznej mierze z zestawu przypadkowych okoliczności ${ }^{3}$. Sytuacjoniści zwrócili uwagę na problematyczność podstawowych założeń przyjmowanych w etyce cnót, jednak ich wnioski wydają się zbyt daleko idące. W literaturze naukowej wskazuje się na to, że środowisko - w tym również wychowanie - ma istotny wpływ na kształtowanie się określonych postaw, motywacji i dyspozycji do działania ${ }^{4}$.

${ }^{2}$ Zob. np. J. Jaśtal (red.), Etyka i charakter, Wydawnictwo Aureus, Kraków 2004; J. Jaśtal, Natura cnoty. Problematyka cnoty w neoarystotelesowskiej etyce cnót, Księgarnia Akademicka, Kraków 2009; N. Szutta, Wspótczesna etyka cnót: projekt nowej etyki?, Wydawnictwo Uniwersytetu Gdańskiego, Gdańsk 2008; N. Szutta, Dyskusja z sytuacjonistyczna krytyka etyki cnót: odpowiedź na zarzuty Gilberta Harmana, „Diametros” 2012, nr 31, s. 88-112; N. Szutta, A. Szutta (red.), W poszukiwaniu moralnego charakteru, Wydawnictwo Academicon, Lublin 2015; N. Szutta, Wychowanie moralne z perspektywy etyki cnót, „Diametros” 2015, nr 46, s. 111-133; N. Szutta, Czy istnieje coś, co zwiemy moralnym charakterem i cnota? Dyskusja z sytuacjonistyczna krytyka etyki cnót, Wydawnictwo Academicon, Lublin 2017. Etyka cnót w ujęciu neoarystotelesowskim nie jest jedyną odmianą etyki cnót, która ma znaczenie we współczesnej myśli etycznej, jednak to ten nurt jest najbardziej popularny, zwłaszcza w filozofii anglosaskiej. Najbardziej znana definicja cnoty, do której nawiązują współcześni kontynuatorzy myśli Arystotelesa, brzmi następująco: „A więc dzielność etyczna jest trwałą dyspozycją do pewnego rodzaju postanowień, polegającą na zachowywaniu właściwej ze względu na nas średniej miary, którą określa rozum, i to w sposób, w jaki by ją określił człowiek rozsądny". Arystoteles, Etyka Nikomachejska, PWN, Warszawa 2012, s. 1107a.

${ }^{3}$ Zob. np. J. Doris, Lack of character. Personality and moral behavior, Cambridge University Press, Cambridge 2002; G. Harman, Moral philosophy meets moral psychology: virtue ethics and the fundamental attribution error, "Proceedings of the Aristotelian Society" 1999, No. 109, s. 316-331; D. Kahneman, Pułapki myślenia. O myśleniu szybkim i wolnym, Media Rodzina, Poznań 2012.

${ }^{4}$ Zob. np. N. Szutta, Dyskusja ..., dz. cyt.; N. Szutta, A. Szutta (red.), W poszukiwaniu ..., dz. cyt.; M. Cohut, Nature vs. nurture: Do genes influence our morals?, "Medical News Today", 27 Feb. 2019, https://www. medicalnewstoday.com/articles/324561.php [dostęp: 6.03.2019]. 
Drugi wymiar krytyki może polegać na postawieniu pytania, czy metody zalecane przez teoretyków etyki cnót i stosowane przez wychowawców zajmujących się praktycznym kształtowaniem cnót nie dyskredytują etyki cnót pod względem moralnym. W niniejszym artykule pominiemy zagadnienia, które nie są w specyficzny sposób związane z etyką cnót, a jedynie znajdują w niej swoje odzwierciedlenie - takie jak problem odpowiedzialności, trafu moralnego lub wolnej woli. Skupimy się na problemach, które w szczególny sposób związane są z praktyką wychowania, a zatem dotyczą praktycznego kształtowania cnót ${ }^{5}$. Do takich problematycznych kwestii należy między innymi wykorzystywanie kategorii wstydu i winy jako regulatorów zachowania wychowanków ${ }^{6}$, korzystanie $z$ technik behawioralnych, a także mechanizm wdrukowania i bezbronność wychowanka wobec autorytetu.

Zależność i bezbronność dziecka wobec autorytetu i mechanizm wdrukowania zdają się budzić największe wątpliwości pod względem moralnym, dlatego skupimy się właśnie na tych problemach. Powszechne istnienie wyżej wymienionych zjawisk, które są ściśle związane z początkowym etapem kształtowania charakteru, dostarcza argumentów na rzecz tezy, że nie ma ostrej linii oddzielającej proces wychowania od indoktrynacji. Problem ten w zwięzły i satyryczny sposób podsumowuje Carl Sagan: „Młode zwierzęta obdarzone są niemal ejdetyczną pamięcią, lecz pozbawione są wszelkich zdolności do krytycznej oceny. Wierzą we wszystko, czego się ich uczy. Jak pokazuje przykład kacząt paradujących z uwielbieniem w ślad za brodatym etologiem, wdrukowanie może prowadzić do nadużyć ze strony pozbawionych skrupułów wyższych zwierząt. Młode z ochotą uczą się, kogo należy kochać, a kogo nienawidzić"7. W dużo bardziej obszerny sposób zagadnienie to zostało omówione przez Denise Winn, która w nawiązaniu do prac Hansa Tocha zauważa ${ }^{8}$, że ,,indoktrynacja, czy jest zamierzona, czy nie, zachodzi w dzieciństwie"9. Winn przypomina o istnieniu czynników, które sprawiają, że dziecko w dużym stopniu narażone jest na indoktrynację i powiązany z nią mechanizm wdrukowania ${ }^{10}$. Pierwszym $\mathrm{z}$ nich jest ograniczona umiejętność percepcji: świat dziecka to przestrzeń, w której centralną rolę pełnią rodzice - „dziecko zaczyna wierzyć w pewne rzeczy, dlatego że nie zna niczego innego" ${ }^{11}$. Drugi czynnik to zależność od opiekunów

5 Omawiane tu zagadnienia są przedstawione w szerszym kontekście w książce: W. Wojtanowska, Filozofia moralna Thomasa Nagela a wspótczesna etyka cnót, Wydawnictwo Naukowe Uniwersytetu Papieskiego Jana Pawła II w Krakowie, Kraków 2019.

${ }^{6}$ Emocja wstydu nie jest w szczególny sposób powiązana z neoarystotelesowską etyką cnót. Należy ją raczej traktować jako często występujący element technik wychowawczych mających na celu kształtowanie charakteru. Sam Arystoteles uznawał znaczenie tej emocji, podkreślając, że jest ona wymagana głównie w okresie młodości. Zob. Arystoteles, dz. cyt., s. 1128b. Zob. też J. Górska, Wstyd jako emocja wywoływana społecznie, „Societas/Communitas” 2012, nr 2(14), s. 179, 184; A. Heller, Power of shame. A rational perspective, Routledge, London 1985, s. 5; B. Williams, Shame and necessity, University of California Press, Berkeley 1993.

7 C. Sagan, A. Druyan, Cienie zapomnianych przodków. W poszukiwaniu naszej tożsamości, Zysk i S-ka, Poznań 2000, s. 189.

${ }^{8}$ H. Toch, The social psychology of social movements, Methuen, London 1966.

9 D. Winn, Manipulowanie umystem: pranie mózgu, warunkowanie, indoktrynacja, Wydawnictwo Unus, Wałbrzych 2003, s. 59.

10 Tamże, s. 64.

11 Tamże, s. 64. 
i wcześnie nabyta wiedza o tym, że opłaca się dostosowywać do oczekiwań. Trzecim problemem jest ograniczenie informacyjne i utrudniona weryfikowalność informacji we wczesnym okresie życia dziecka, a czwarty element to naturalna potrzeba wzorowania się na ojcu lub matce. Wymienione powyżej punkty współtworzące mechanizm wdrukowania wzmacniają późniejszą gotowość percepcyjną na określone bodźce: „Proces ten ma swoje źródło w fizjologii. Gdybyśmy mieli reagować na każdy bodziec w naszym otoczeniu, nasz system nerwowy byłby przeładowany i załamałby się. Musimy zatem stosować selekcję" $"$. Nieświadoma gotowość percepcyjna na bodźce, które do nas docierają, ma istotne znaczenie w deformowaniu obrazu poszczególnych elementów rzeczywistości, co z kolei ma nieuświadomiony wpływ na formułowane oceny etyczne określonych zjawisk. Obecność tych mechanizmów świadczy o tym, że wychowanie polegające na kształtowaniu cnót obejmuje również elementy typowe dla procesów indoktrynacji. Może to być argumentem na korzyść tezy, że wato jest podjąć wysiłki w celu położenia akcentów na inne elementy służące do budowania ludzkiej moralności i doskonalenia ludzkich charakterów, co może przyczynić się do udoskonalenia samej etyki cnót pod względem etycznym. Często bowiem nie zdajemy sobie sprawy z wpływu powyższych mechanizmów na posiadane przekonania i cechy charakteru. Uświadomienie sobie oraz innym tych zjawisk stanowi niezbędną podstawę do tego, aby chociaż w pewnym stopniu można było im przeciwdziałać ${ }^{13}$. Chociaż bowiem etyka cnót nie jest w stanie zlikwidować powyższego problemu, to wydaje się, że istnieje możliwość jego złagodzenia.

\section{Etyka cnót a niedyrektywny model wychowania}

W obecnych czasach takie rozumienie cnót, które kładzie nacisk na ich kognitywny aspekt, wydaje się szczególnie istotne między innymi dlatego, że wraz z rozwojem technologii zwiększają się techniczne możliwości przeprowadzania różnego typu manipulacji w rozmaitych sferach życia społecznego ${ }^{14}$. Ze względu na współczesne możliwości manipulacji ludzkim umysłem zarówno w wymiarze indywidualnym, jak i zbiorowym przed etyką cnót pojawia się dodatkowe pytanie o to, jakie są skuteczne sposoby obrony przed tymi działaniami. Od tradycyjnych i behawioralnych sposobów wdrażania cnót, w dużym stopniu bazujących na elementach bezkrytycznego zaufania do autorytetu, bardziej obiecujące wydaje się współczesne, kognitywno-afektywne ujęcie cnoty, rozwijane na gruncie filozofii polskiej na przykład przez Nataszę Szuttę. Nie jest ono jednak wolne od trudności, co postaramy się wykazać w dalszej części artykułu.

Rozwijając neoarystotelesowską etykę cnót, N. Szutta często odwołuje się do myśli Stagiryty. Dla samego Arystotelesa charakterystyczne było z jednej strony podkreślanie

12 Tamże, s. 65.

13 Por tamże, s. 66.

14 Zob. np. R.L. Sandler (red.), Ethics and emerging technologies, Palgrave Macmillan, Boston 2014, s. 13 i nast.; L. Winner, Technologies as forms of life, [w:] R.L. Sandler (red.), Ethics and emerging technologies, Palgrave Macmillan, Boston 2014, s. 51, 53; W. Glannon, Psychofarmacology and functional neurosurgery: manipulating memory, thought and mood, [w:] R.L. Sandler (red.), Ethics and emerging technologies, Palgrave Macmillan, Boston 2014, s. 167-179. 
roli rozumu w kształtowaniu cnót, a z drugiej strony silny nacisk na to, że początek edukacji moralnej opiera się przede wszystkim na zaufaniu do autorytetu wychowawcy, posłuszeństwie i dyscyplinie ${ }^{15}$. Broniąc etyki cnót, N. Szutta argumentuje, że behawioralne rozumienie cnoty, polegające na utrwalaniu prostych i bezrefleksyjnych nawyków, stanowi jedynie początek edukacji moralnej we wczesnym okresie rozwoju wychowanka ${ }^{16}$. Stopniowo jest ono uzupełniane o elementy afektywne, które pełnią istotną rolę w układzie motywacyjnym podmiotu, oraz kognitywne, polegające na uświadamianiu złożoności problematyki moralnej, uczeniu roztropności i ostrożności w ocenach moralnych. Dlatego jeden z głównych zarzutów - utożsamiający wdrażanie cnoty z indoktrynacją - jest według niej nieadekwatny ${ }^{17}$. Ponadto $\mathrm{w}$ swojej polemice $\mathrm{z}$ niedyrektywnymi metodami wychowania moralnego przedstawia argumenty mające na celu wykazanie, że przeciwko niedyrektywnym metodom wychowawczym można w zasadzie wysunąć podobne obiekcje, jak wobec etyki cnót ${ }^{18}$.

Trudno nie zgodzić się z tezą, że zarzut indoktrynacji jest w dużym stopniu osłabiony w przypadku afektywno-kognitywnego rozumienia cnoty. Jednak wydaje się, że zbyt uproszczone byłoby stwierdzenie, że w takim ujęciu w ogóle nie ma on zastosowania. Chociaż elementy habituacji są w późniejszym okresie życia dziecka uzupełniane o aspekty kognitywne i afektywne, to jednak w początkowym okresie wyuczanie prostych schematów behawioralnych jest podstawą edukacji moralnej ${ }^{19}$. Przede wszystkim rodzi to problemy związane ze wspomnianym powyżej zjawiskiem wdrukowania. Warto również zauważyć, że w modelu kognitywno-afektywnym pierwotne metody, stosowane w początkowych latach życia dziecka, w późniejszym okresie nie zostają całkowicie wyeliminowane. Gdyby tak było, mielibyśmy bowiem do czynienia z sytuacją, gdy behawioralne rozumienie cnoty przechodzi stopniowo w model niedyrektywny - jednak nie na tym polega ujęcie afektywno-kognitywne. Nadal bowiem kluczową rolę pełni utrwalanie dyspozycji oraz zaufanie do autorytetu ${ }^{20}$.

N. Szutta podkreśla, że edukacja moralna powinna zaczynać się od prostego modelu behawioralnego i dopiero z czasem ,miejsce nawyków powinny zająć właściwie rozumiane cnoty. Dziecko, stawiając różne pytania i poszukując najlepszych odpowiedzi,

\footnotetext{
15 Arystoteles, dz. cyt., s. 1118 b.

16 Por. „Trudno oczywiście wyobrazić sobie wychowanie moralne w duchu właściwie rozumianych cnót na poziomie wczesnej edukacji. W tym okresie znacznie ważniejsze jest wypracowanie pewnych nawyków, które następnie mogą być rozwinięte w kognitywno-afektywnie rozumiane cnoty etyczne, gdy dziecko osiągnie wyższy stopień dojrzałości intelektualnej i emocjonalnej. Behawioralnie rozumiane cnoty mogą stanowić początek wdrażania dziecka w podejmowanie moralnych decyzji”. N. Szutta, Wychowanie moralne..., dz. cyt., s. 118.

17 Tamże, s. 117, 123-128. Indoktrynacja jest przez N. Szuttę zdefiniowana jako „świadome i systematyczne wpajanie komuś «jedynie słusznych» przekonań, bez jakiegokolwiek uzasadniania, metodami nieracjonalnymi, wykorzystując proste i nieświadome warunkowanie zachowania. Indoktrynacja nie dopuszcza krytyki i kwestionowania propagowanych wartości”. Tamże, s. 123. Zasadniczo przyjmuję w tym artykule definicję indoktrynacji zaproponowaną przez N. Szuttę, z zastrzeżeniem, iż wydaje się, że niesłuszne jest włączenie do definicji indoktrynacji sformułowania „,bez jakiegokolwiek uzasadniania”, ponieważ nawet najbardziej totalitarne reżimy, indoktrynując ludzi, zazwyczaj podawały jakieś uzasadnienie - często była nim określona ideologia lub religia.

${ }_{18}$ Tamże, s. 123-127.

19 Tamże, s. 118, 120.

${ }^{20}$ Zob. np. tamże, s. 116.
} 
powinno stopniowo przestać postępować automatycznie według ustalonych wcześniej schematów"21. Pojawia się tu jednak zasygnalizowany powyżej problem. Można bowiem postawić pytanie, w jaki sposób ludzie mają być zdolni do krytycznej (ale mądrze krytycznej) oceny wcześniej przekazywanych im poglądów i do dostrzegania złożoności problematyki moralnej, jeśli w okresie dzieciństwa - czyli wtedy, gdy ich psychika jest najbardziej podatna na procesy wdrukowania i utrwalenie się określonych dyspozycji są wychowywani do automatycznych reakcji i całkowitego zaufania do autorytetu. Jeśli krytyczne myślenie nie jest wspierane w okresie wczesnego dzieciństwa, czyli wówczas, gdy tworzą się podstawowe dyspozycje moralne i intelektualne, to czy później nie jest już za późno na to, aby w optymalny sposób wykształciła się umiejętność sprawnego myślenia i oszacowywania przekazywanych zasad i wytycznych? Czy rzeczywiście w późniejszym wieku możliwe jest (chodzi tu o powszechną praktykę, a nie działanie jednostek o wyjątkowych cechach) skuteczne rezygnowanie z wcześniej wdrożonych i utartych schematów, upraszczających złożoność problematyki moralnej?

Zatem można stwierdzić, że ujęcie to nie jest wolne od wewnętrznych trudności, pojawiają się tu bowiem trudne kwestie dotyczące omówionego powyżej mechanizmu wdrukowania: elementy kognitywno-afektywne wprowadzane są już po tym, jak umysł wychowanka został w znacznym stopniu pozbawiony umiejętności dystansowania się do przekazywanych treści i rozpoznawania dokonywanej indoktrynacji lub manipulacji. Można więc postawić pytanie o to, czy późniejszy proces zastępowania prostych nawyków refleksyjnością i wielostronnym spojrzeniem ma szanse odbywać się w sposób skuteczny i czy w praktyce wychowania proces ten odbywa się w sposób optymalny.

Przedstawiona powyżej teza dotycząca zacierania się różnicy pomiędzy tradycyjnym wychowaniem i indoktrynacją może zostać uznana za kontrowersyjną lub zbyt mocną i z pewnością można z nią dyskutować, jednak wydaje się, że nie należy ignorować wyżej wymienionych mechanizmów i problemów lub stwierdzać a priori, że nie ma możliwości ich złagodzenia ani częściowego rozwiązania. Zanim jednak podejmiemy próbę złagodzenia tego dylematu poprzez zbliżenie etyki cnót do modelu niedyrektywnego, należy zadać pytanie, czy faktycznie może to przynieść jakąś korzyść pod względem etycznym. Pytanie to jest zasadne między innymi dlatego, że N. Szutta argumentuje, iż metody niedyrektywne przynajmniej w jakimś stopniu narażone są na podobne zarzuty, co etyka cnót.

N. Szutta w trafny sposób ujmuje istotę metod niedyrektywnych, pisząc, że „,w niedyrektywnych koncepcjach celem edukacji moralnej jest ukształtowanie intelektualnych procesów, które pozwalają wychowankom samodzielnie dochodzić do moralnych przekonań, doskonalić techniki moralnego rozumowania i selekcjonowania wartości"22. W związku z tym zauważa ona, iż nawet w ujęciach niedyrektywnych występują pewne założenia na temat przewagi określonych wartości moralnych, takich jak otwartość, tolerancja, krytycyzm i zaufanie do własnego rozumu. Założenia te w modelu niedyrektywnym mają charakter ukierunkowujący praktyki moralne - nie jest to zatem taki model wychowania, który w żaden sposób nie steruje poglądami i zachowaniem wychowanka. Można jednak kontrargumen-

21 Tamże, s. 120.

22 Tamże, s. 122. 
tować, że jedną z podstawowych cech indoktrynacji jest wdrażanie do bezkrytycznego przyjmowania poglądów swoich wychowawców, a wymienione przez N. Szuttę wartości, które promowane są w ujęciu niedyrektywnym, stanowią zaprzeczenie takiego podejścia. Chociaż pod względem formalnym można uznać, że również w modelu niedyrektywnym mamy do czynienia z pewnym śladem indoktrynacji, to jednak zarzut indoktrynacji jest znacznie bardziej adekwatny w etyce cnót ze względu na to, że istotną rolę pełnią w niej zaufanie do autorytetu i habituacja wdrażana od pierwszych lat życia wychowanka.

Zatem wydaje się, że jednym ze sposobów łagodzenia omawianego konfliktu moralnego wewnątrz etyki cnót może być postulat jak najwcześniejszego zbliżenia jej do modelu niedyrektywnego, co mogłoby zostać częściowo zrealizowane między innymi poprzez wzrost znaczenia tych cnót, które w szczególny sposób łączą w sobie wymiar etyczny i intelektualny. Poniżej podejmę próbę wykazania, że etyka oparta na pojęciu racji może zostać włączona do rozważań w ramach etyki cnót i może stanowić jeden z elementów służących do nadania jej mniej dyrektywnego charakteru. Ze względu na ramy artykułu skupię się na rozważeniu przydatności typologii racji zaproponowanej przez Thomasa Nagela. Może mieć ona zastosowanie we współczesnej etyce cnót na dwóch płaszczyznach. Po pierwsze, dyspozycja do ważenia racji różnego typu spełnia wymogi umożliwiające potraktowanie jej jako jednej z cnót, związanej ze zdolnością do trafnego osądu moralnego i z doskonaleniem rozumowania praktycznego. Dyspozycja taka wzbogaca katalog cnót o cenny element i może być jednym ze sposobów realizacji postulatu zbliżania tego nurtu do modelu niedyrektywnego. Oprócz tego zasygnalizuję, że zastosowanie Nagelowskiej typologii racji w etyce cnót może mieć szerszy wymiar, ponieważ może wiązać się z ograniczeniem przytoczonych powyżej wątpliwych metod kształtowania charakteru.

\section{Nagelowska typologia racji do działania a neoarystotelesowska etyka cnót}

We współczesnej myśli etycznej pojawiają się koncepcje, które rozwijają neoarystotelesowskie ujęcie cnót, a jednocześnie podkreślają znaczenie zdolności do prawidłowego rozpoznawania racji moralnych. Samo pojęcie racji praktycznych jest złożone i na jego temat powstała obszerna literatura ${ }^{23}$. Aby nie odchodzić od meritum omawianego problemu, w tym artykule przyjmujemy najbardziej ogólną definicję, mówiącą, że racje to „wszystkie czynniki i okoliczności” ${ }^{24}$, które należy wziąć pod uwagę przy podejmowaniu decyzji. W propozycjach etycznych opartych na pojęciu racji kładzie się nacisk na ko-

${ }^{23}$ Zob. np. M. Rutkowski, Dlaczego potrafimy działać moralnie?, Wydawnictwo Naukowe Scholar, Warszawa 2010; T. Żuradzki, Internalizm i eksternalizm w metaetyce, Wydawnictwo Uniwersytetu Jagiellońskiego, Kraków 2012; M. Pyka, Działanie, moralność, podmiotowość: wokół myśli Thomasa Nagela, Wydawnictwo Księgarnia Akademicka, Kraków 2016. Zob. też J. Lenman, Reasons for Action: Justification, Motivation, Explanation, https://plato.stanford.edu/entries/reasons-just-vs-expl/ [dostęp: 4.09.2019].

${ }^{24}$ M. Pyka, dz. cyt., s. 21. Mówiąc ściślej, wszystkie brane pod uwagę czynniki to racje prima facie. W drugim znaczeniu racja do określonego działania dotyczy już podjętej decyzji, w której stwierdzamy, że w danej sytuacji mamy rację, aby coś zrobić i (być może) decydujemy się na to działanie. 
gnitywny aspekt decyzji moralnych i zdolność do rozumowania praktycznego - zatem powiązanie etyki cnót z koncepcjami tego typu w specyficzny sposób zbliża ją do modelu niedyrektywnego. Przykładami takich rozwiązań mogą być koncepcje Johna McDowella, Roberta Audiego, Bernarda Williamsa lub Marthy Nussbaum.

W niniejszym artykule proponujemy zwrócenie uwagi na filozofię moralną Thomasa Nagela, ponieważ wydaje się, że powiązanie jej z etyką cnót otwiera interesujące perspektywy badawcze. Chociaż Nagel nie rozwija swojej propozycji w kierunku etyki cnót, w literaturze wtórnej zwrócono uwagę na to, że podjęcie takiej próby jest możliwe lub nawet wskazane ${ }^{25}$. Nieredukcjonistyczne podejście Nagela znane i wpływowe jest przede wszystkim w filozofii umysłu, jednak ma ono zastosowanie również w teorii etycznej. Dostrzeżenie faktu, że w ludzkiej podmiotowości współistnieją dwie perspektywy (internal and external standpoint) pozwala odnaleźć uniwersalne podłoże wspólne wszystkim ludziom, a jednocześnie dopuszcza pewną elastyczność i uwzględnia pluralizm wartości i racji ${ }^{26}$. Powiązanie racji moralnych ze współwystępowaniem oraz nieredukowalnością i równoprawnością wewnętrznego i zewnętrznego punktu widzenia ma znaczący wpływ na jego propozycje z zakresu etyki, ponieważ współistnienie dwóch perspektyw stanowi uzasadnienie występowania i wzajemnego równoważenia się różnych typów wartości i racji. Jeśli wewnętrzna i zewnętrzna perspektywa są równie realne, równie niezastępowalne i konieczne w swoim współistnieniu, to oznacza również prawomocność różnego typu racji - tych związanych z wewnętrzną, jak i zewnętrzną perspektywą. Poniżej w skrótowy sposób przypomnimy typologię racji zaproponowaną przez Thomasa Nagela, a następnie pokażemy, w jaki sposób to zagadnienie można powiązać z etyką cnót.

Perspektywę zewnętrzną podmiotu wyrażają racje podmiotowo neutralne (bezstronne), które charakteryzują się tym, że „nie zależą od szczególnej perspektywy i systemu preferencji podmiotu działającego" ${ }^{27}$, czyli „każda osoba ma powód, żeby chcieć, aby to się zdarzyło"28. Związane są one z moralnym wymogiem promowania pewnych fundamentalnych wartości - przede wszystkim dotyczy to dążenia do minimalizowania bólu i cierpienia. Teorie etyczne typu konsekwencjonalistycznego oparte są na racjach tego typu. Natomiast inne propozycje etyczne mogą brać pod uwagę także racje wyrażające perspektywę wewnętrzną (racje względne wobec podmiotu) ${ }^{29}$. Nagel proponuje uznanie trzech rodzajów racji względnych: racji autonomii, deontycznych i zobowiązań ${ }^{30}$.

25 Por. D.C. Russel, Practical Intelligence and the virtues, Oxford University Press, Oxford 2009, s. 340; N.J.H. Dent, The moral psychology of the virtues, Cambridge University Press, Cambridge 1984, s. 95; C.A.J. Coady, Morality and Political Violence, Cambridge University Press, Cambridge 2008, s. 200; A. Thomas, Thomas Nagel, McGill-Queens University Press, Montreal [etc.] 2009, s. 134. Uwagi powyższych autorów dotyczące możliwości powiązania koncepcji Nagela z etyką cnót są bardzo lakoniczne, jednak mogą stanowić interesujący punkt wyjścia do dalszych rozważań w tym kierunku.

26 T. Nagel, Pytania ostateczne, Fundacja Aletheia, Warszawa 1997, s. 161-176. Zob. też T. Nagel, Equality and Partiality, Oxford University Press, New York-Oxford 1991 oraz M. Pyka, dz. cyt.; B. Polanowska-Sygulska, Pluralizm wartości i jego implikacje w filozofii prawa, Księgarnia Akademicka, Kraków 2008.

27 T. Nagel, Widok zniką, Fundacja Aletheia, Warszawa 1997, s. 208.

28 Tamże, s. 188.

29 Tamże, s. 186-187.

${ }^{30}$ Nagel stosuje termin racje obowiązku, ale sam stwierdza, że nie jest z niego zadowolony. W literaturze wtórnej jest stosowana nazwa racje zobowiazań. Zob. M.. Pyka, dz. cyt. 
Racje autonomii są najbardziej skrajną formą względności wobec podmiotu, ponieważ wyrażają osobiste interesy, plany i pragnienia. Każda jednostka ma do nich prawo, jednak nie zobowiązują one innych osób, żeby je promować ${ }^{31}$. Ich istnienie rozwiązuje problem nadmiernie wymagającej etyki, z którym zmagają się systemy etyczne typu konsekwencjonalistycznego. Racje deontyczne przede wszystkim wyrażają roszczenia do tego, aby nie być traktowanym w nieodpowiedni sposób, a zatem „ograniczają działania, które wolno nam podejmować w służbie wartości bezosobowych lub autonomicznych"32. Wiążą się one z osobową relacją pomiędzy ludźmi i tym, jakie działania wobec innej osoby są niedopuszczalne. $Z$ kolei racje zobowiązań dotyczą relacji z ludźmi, z którymi daną osobę łączą szczególne więzy - naturalne lub o charakterze społecznym. Pozwalają one uzasadnić szczególne preferencje, jakimi jednostka powinna się kierować w swoich wyborach, i usprawiedliwiają specjalną troskę o najbliższych lub walkę o interesy określonych grup.

Uznanie prawomocności zaproponowanych typów racji pozwala uniknąć licznych problemów i paradoksów, do których prowadzi przyjęcie stanowisk takich jak konsekwencjonalizm lub etyka kantowska, bazujących na jednym typie racji. Wydaje się więc, że przedstawiona przez Nagela typologia racji do działania, będąca wyrazem przyjęcia przez niego koncepcji pluralizmu etycznego, jest w ogólnym zarysie propozycją wiarygodną i akceptowalną bez względu na różne możliwe założenia metafizyczne, a ponadto pozwala lepiej zrozumieć, a nawet częściowo rozwiązać podstawowe dylematy etyczne. W związku z tym można poszukiwać sposobów na zwiększenie wykorzystania tej koncepcji nie tylko w rozważaniach teoretycznych, ale również w odniesieniu do istniejących praktyk moralnych. Jedną z możliwości mogłoby być potraktowanie zdolności do ważenia racji jako istotnej dyspozycji, którą należy kształtować już od wczesnych lat życia dziecka.

W publikacjach poświęconych myśli etycznej zwraca się uwagę na to, że teoria złotego środka w odniesieniu do wielu kwestii okazuje się adekwatna i może mieć zastosowanie $\mathrm{w}$ wielu różnych dziedzinach i sytuacjach ${ }^{33}$. Wydaje się więc, że takie ogólne rozumienie złotego środka można odnieść również do ważenia różnych typów racji. Rozumowanie praktyczne, w tym podejmowanie decyzji o charakterze moralnym, związane jest między innymi z odnalezieniem właściwego stopnia obiektywizacji - w decyzjach moralnych wyraża się to w znalezieniu właściwego środka polegającego na zważeniu różnego typu racji prima facie mających znaczenie w danych okolicznościach. W danej sytuacji może występować wielość racji prima facie należących do wszystkich lub tylko niektórych typów. System motywacyjny jest więc „,popychany” w różnych kierunkach i narażony na duże niebezpieczeństwo przypadkowości - w szczególności gdy podmiot nie jest świadomy istnienia różnych typów racji. Wydaje się również, że jednorazowa informacja nie jest wystarczająca do tego, aby różne typy racji były systematycznie rozpoznawane i uwzględniane. Potrzebny jest raczej pewien długotrwały wysiłek podmiotu, aby zarówno u niego samego, jak i u wychowanków ukształtowały się dyspozycje do rozpoznawania

31 T. Nagel, Widok znikad, dz. cyt., s. 202, 204.

32 Tamże, s. 245.

33 Zob. np. B. Russell, The conquest of happiness, Unwin Books, London 1968, s. 148; J.L. Mackie, Ethics: Inventing Right and Wrong, Penguin Books, Harmonsworth 1977. 
normatywnej złożoności otaczającej rzeczywistości. Nieświadomość istnienia różnych typów racji lub brak umiejętności ich uwzględniania może prowadzić do podejmowania niewłaściwych decyzji lub błędnych sądów wartościujących. Może również przyczynić się do tego, że charakter wychowanków kształtowany będzie w taki sposób, że tylko określone typy racji będą brane pod uwagę w systemie motywacyjnym danej osoby.

Związek pomiędzy zdolnością do rozpoznawania i uwzględniania racji różnego typu a cechami charakteru nie budzi szczególnego zainteresowania etyków cnót, tymczasem powiązanie takie wydaje się dosyć istotne. Można to wykazać za pomocą kilku przykładów: osoba, która nie rozpoznaje wagi racji zobowiązań, może aktywnie włączać się w walkę o słuszne ideały, przy jednoczesnym zaniedbywaniu potrzeb najbliższych osób. Ktoś, kto ignoruje racje deontyczne, a jest na przykład policjantem, może być gotowy poświęcić niewinną osobę dla uratowania porządku społecznego (w historii znane były aresztowania niewinnych osób pełniących rolę „kozłów ofiarnych” po to, aby zapobiec zamieszkom itd.). Urzędnik lub policjant, który przecenia rolę racji deontycznych w ich kantowskim, formalistycznym rozumieniu, będzie uznany za bezdusznego służbistę, któremu obce są ludzkie odruchy. Natomiast ci, którzy w sposób nadmierny kierują się racjami autonomii, wykazują cechy egoistów lub egocentryków. Zatem staje się widoczne, że umiejętność prawidłowego rozpoznania i ważenia racji ma wyraźny wpływ na kształtowanie charakteru, a uwrażliwianie na moralną potrzebę uwzględniania różnorodnych racji może przyczynić się do zapobiegania postawom i dyspozycjom, które charakteryzują się ślepotą na normatywną złożoność napotkanych dylematów moralnych.

Zdolność do ważenia racji może zostać uznana za aspekt mądrości praktycznej, i w takim szerokim sensie nawiązuje do myśli Arystotelesa. Umiejętność ta mieści się więc $\mathrm{w}$ arystotelesowskim rozumieniu mądrości praktycznej pod względem formalnym, jednak wykracza poza nią pod względem treści, ponieważ odnosi się do racji, a ponadto dotyczy racji różnych typów, jako że zaproponowane tu ujęcie nawiązuje do pluralizmu etycznego Nagela.

Jeśli racje odnoszą się do czynników i okoliczności, jakie należy brać pod uwagę przy podejmowaniu decyzji ${ }^{34}$, to warto zauważyć, że taka propozycja może współgrać z kontekstualnym charakterem etyki cnót, na który kładzie nacisk Natasza Szutta ${ }^{35}$. Wynika z tego, że postulat jak najwcześniejszego uczenia zdolności do ważenia racji wbrew pozorom nie stoi w sprzeczności z założeniami etyki cnót ani nie musi oznaczać wprowadzania modelu niedyrektywnego w miejsce etyki cnót. Zdolność do ważenia racji może bowiem zostać potraktowana jako jedna z cnót, która łączy w sobie wymiar etyczny i intelektualny. Wrażliwość na kontekst sytuacyjny i złożoność problematyki

${ }^{34}$ Aby nie odchodzić od głównego problemu, nie analizujemy tu różnych ontologicznych możliwości, jeśli chodzi o sposób istnienia racji. Wydaje się, że proponowane ujęcie może być zaakceptowane zarówno przez zwolenników realizmu racji, do których należy Nagel, jak i na przykład przez przedstawicieli konstruktywizmu.

${ }^{35}$ N. Szutta, Wychowanie moralne ..., dz. cyt., s. 115-117. Propozycja uwrażliwiania dzieci na złożoność problematyki moralnej oraz uczenie dostrzegania i uwzględniania rozmaitych czynników (czyli de facto racji różnego typu) przy podejmowaniu decyzji w określonych, faktycznie występujących sytuacjach, jest odporna na zarzut Nataszy Szutty wobec metod niedyrektywnych, które propagują edukację moralną polegającą na rozważaniu abstrakcyjnych dylematów (tamże, s. 122). 
moralnej może współistnieć zarówno z przyswajaniem pewnych ogólnych zasad, jak i z kształtowaniem różnorodnych cnót.

Kolejnym wymiarem wykorzystania współistnienia różnych typów racji w etyce cnót mogłoby być nałożenie moralnych ograniczeń na metody stosowane w procesie kształtowania charakteru. Jedno $\mathrm{z}$ istotnych ograniczeń w odniesieniu do metod wychowania stanowią racje autonomii ${ }^{36}$. Wzmacniają one argumenty na rzecz wprowadzenia zindywidualizowanych metod wychowawczych i elastyczności, jeśli chodzi o oczekiwania wobec wychowanków. Czynnikiem mającym charakter ograniczający jest również istnienie racji deontycznych. Nagel poświęca wiele miejsca na obronę ich zasadności, dlatego jest uznawany za jednego z najważniejszych współczesnych przedstawicieli deontologii ${ }^{37}$. Rozpoznanie ważności racji deontycznych ma istotne znaczenie w procesie kształtowania pożądanych cech charakteru - pozwala bowiem unaocznić to, że jeśli stosowane przez jakąś osobę lub instytucję metody wychowawcze obejmują na przykład zastraszanie, naruszanie prywatności lub pozbawianie poczucia własnej wartości, to bez względu na stawiane cele poprzez swoje metody działania dają one rację ku temu, aby autorytet wychowawcy został zakwestionowany. Zatem uznanie prawomocności różnych typów racji zaproponowanych przez Nagela może mieć wpływ na proces kształtowania cnót na kilku poziomach. Od strony teoretycznej typologia racji może służyć jako element rozpoznania złożoności problematyki moralnej. Od strony praktycznej ma zastosowanie na poziomie wychowawcy przy wdrażaniu wychowanka do rozpoznania różnego typu racji i do nabywania umiejętności znajdowania pomiędzy nimi właściwego w danej sytuacji „środka”, a także jako ograniczenie dopuszczalnych metod. Na poziomie wychowanka może wspomóc moralne uzasadnienie odmowy uznania autorytetu wychowawcy, jeśli łamie on zasady związane $\mathrm{z}$ racjami deontycznymi i racjami autonomii. $\mathrm{W}$ ten sposób zastosowanie przedstawionej typologii racji może być jednym z elementów zbliżania etyki cnót do modelu niedyrektywnego, akcentującego umiejętność krytycznego myślenia i wnikliwej oceny otaczającej rzeczywistości.

\section{Podsumowanie}

Rozpoznanie złożoności problematyki moralnej prowadzi do wniosku, że współistnienie różnych typów racji powinno być uwzględnione w procesie formowania stałych dyspozycji, które przejawiają się w podejmowanych decyzjach i działaniu. Uwrażliwianie wychowanków na pojawianie się w określonych sytuacjach różnorodnych typów racji o różnej wadze powinno być stałym elementem edukacji moralnej i może stanowić ten aspekt kognitywno-afektywnego ujęcia etyki cnót, który najbardziej zbliża ją do modelu niedyrektywnego. Wydaje się, że warto podjąć taką próbę, ponieważ model niedyrektywny w najdalszy sposób odchodzi od metod typowych dla indoktrynacji i umożliwia kształtowanie elastyczności, wnikliwości i krytycyzmu.

${ }^{36}$ Stanowią takie ograniczenie zarówno w sensie faktycznym (racje w sensie wyjaśniającym), jak i normatywnym (racje w sensie uzasadniającym).

${ }^{37}$ T. Nagel, Pytania ostateczne, dz. cyt., s. 71-95; T. Nagel, Widok znikad, dz. cyt., s. 214-219. 
Akceptacja Nagelowskiej typologii racji mogłaby mieć również dodatkowe znaczenie w procesie wychowania. Wiąże się bowiem z problematyką dopuszczalnych metod (racje deontyczne), a także z koniecznością uwzględnienia indywidualności i potrzeb wychowanków (racje autonomii). Współistnienie rożnych typów racji ma więc znaczenie co najmniej dwustopniowe: z jednej strony wyraża się materialnie w przekazywanej treści, która powinna obejmować kształtowanie dyspozycji do uwzględniania poszczególnych typów racji, a z drugiej strony dotyczy metod stosowanych w procesie kształtowania charakteru. Uwidacznia się tu jedno z trudniejszych wyzwań w dziedzinie mądrości praktycznej - pogodzenie oczekiwań dziecka w kwestii uzyskiwania klarownych komunikatów w dziedzinie praktyk moralnych z koniecznością nauczenia elastyczności i umiejętności spoglądania na problemy moralne $\mathrm{z}$ różnorakich perspektyw.

\section{Bibliografia}

Arystoteles, Etyka Nikomachejska, PWN, Warszawa 2012.

Coady C.A.J., Morality and Political Violence, Cambridge University Press, Cambridge 2008.

Cohut M., Nature vs. nurture: Do genes influence our morals?, "Medical News Today", 27 Feb. 2019, https:/www.medicalnewstoday.com/articles/324561.php [dostęp: 6.03.2019].

Dent N.J.H., The moral psychology of the virtues, Cambridge University Press, Cambridge 1984.

Doris J., Lack of character. Personality and moral behavior, Cambridge University Press, Cambridge 2002.

Glannon W., Psychofarmacology and functional neurosurgery: manipulating memory, thought and mood, [w:] R.L. Sandler (red.), Ethics and emerging technologies, Palgrave Macmillan, Boston 2014.

Górska J., Wstyd jako emocja wywoływana społecznie, „Societas/Communitas” 2012, nr 2(14).

Harman G., Moral philosophy meets moral psychology: virtue ethics and the fundamental attribution error, "Proceedings of the Aristotelian Society" 1999, No. 109.

Heller A., Power of shame. A rational perspective, Routledge, London 1985.

Jaśtal J. (red.), Etyka i charakter, Wydawnictwo Aureus, Kraków 2004.

Jaśtal J., Natura cnoty. Problematyka cnoty w neoarystotelesowskiej etyce cnót, Księgarnia Akademicka, Kraków 2009.

Kahneman D., Pułapki myślenia. O myśleniu szybkim i wolnym, Media Rodzina, Poznań 2012.

Lenman J., Reasons for Action: Justification, Motivation, Explanation, https://plato.stanford. edu/entries/reasons-just-vs-expl/ [dostęp: 4.09.2019].

Mackie J.L., Ethics: Inventing Right and Wrong, Penguin Books, Harmonsworth 1977.

Nagel T., Equality and partiality, Oxford University Press, New York 1991.

Nagel T., Pytania ostateczne, Fundacja Aletheia, Warszawa 1997.

Nagel T., Widok znikąd, Fundacja Aletheia, Warszawa 1997. 
Polanowska-Sygulska B., Pluralizm wartości i jego implikacje w filozofii prawa, Księgarnia Akademicka, Kraków 2008.

Pyka M., Działanie, moralność, podmiotowość: wokół myśli Thomasa Nagela, Księgarnia Akademicka, Kraków 2016.

Russel D.C., Practical Intelligence and the virtues, Oxford University Press, Oxford 2009.

Russell B., The conquest of happiness, Unwin Books, London 1968.

Rutkowski M., Dlaczego potrafimy działać moralnie?, Wydawnictwo Naukowe Scholar, Warszawa 2010.

Sagan C., Druyan A., Cienie zapomnianych przodków. W poszukiwaniu naszej tożsamości, Zysk i S-ka, Poznań 2000.

Sandler R.L. (red.), Ethics and emerging technologies, Palgrave Macmillan, Boston 2014.

Szutta N., Czy istnieje coś, co zwiemy moralnym charakterem i cnota? Dyskusja z sytuacjonistyczna krytyka etyki cnót, Wydawnictwo Academicon, Lublin 2017.

Szutta N., Dyskusja z sytuacjonistyczna krytyka etyki cnót: odpowiedź na zarzuty Gilberta Harmana, „Diametros” 2012, nr 31.

Szutta N., Współczesna etyka cnót: projekt nowej etyki?, Wydawnictwo Uniwersytetu Gdańskiego, Gdańsk 2008.

Szutta N., Wychowanie moralne z perspektywy etyki cnót, „Diametros” 2015, nr 46.

Szutta N., Szutta A. (red.), W poszukiwaniu moralnego charakteru, Wydawnictwo Academicon, Lublin 2015.

Thomas A., Thomas Nagel, McGill-Queens University Press, Montreal [etc.] 2009.

Toch H., The social psychology of social movements, Methuen, London 1966.

Williams B., Shame and necessity, University of California Press, Berkeley 1993.

Winn D., Manipulowanie umystem: pranie mózgu, warunkowanie, indoktrynacja, Wydawnictwo Unus, Wałbrzych 2003.

Winner L., Technologies as forms of life, [w:] R.L. Sandler (red.), Ethics and emerging technologies, Palgrave Macmillan, Boston 2014.

Wojtanowska W., Filozofia moralna Thomasa Nagela a wspótczesna etyka cnót, Wydawnictwo Naukowe Uniwersytetu Papieskiego Jana Pawła II w Krakowie, Kraków 2019.

Żuradzki T., Internalizm i eksternalizm $w$ metaetyce, Wydawnictwo Uniwersytetu Jagiellońskiego, Kraków 2012.

\section{Streszczenie \\ O możliwości zastosowania Nagelowskiej typologii racji do działania we współczesnej etyce cnót}

$\mathrm{W}$ artykule podejmuję próbę wzięcia udziału w dyskusji odbywającej się $\mathrm{w}$ ramach współczesnej etyki cnót. Przedstawiam jeden z głównych problemów związanych z procesem kształtowania cnót i argumentuję, że większe zbliżenie etyki cnót do modelu 
niedyrektywnego pozwoliłoby zmniejszyć adekwatność zarzutów wysuwanych wobec metod i mechanizmów wykorzystywanych w procesie kształtowania charakteru. Jako jeden z możliwych sposobów zbliżenia etyki cnót do modelu niedyrektywnego wskazuję uwzględnienie zagadnienia Nagelowskiej typologii racji do działania.

Słowa kluczowe: etyka cnót, wychowanie, racje do działania, Thomas Nagel, pluralizm etyczny

\section{Summary \\ On the possibility of applying Nagel's typology of reasons for action in contemporary virtue ethics}

In this article, I contribute to the discussion on contemporary virtue ethics. I present one of the major problems connected with moral education and I argue that modifying virtue ethics in order to make it more similar to the non-directive model would reduce the strength of some of the objections against the methods and mechanisms used in the process of shaping character. As one of the possible ways of bringing virtue ethics closer to the non-directive model I suggest taking into account Thomas Nagel's typology of reasons for action.

Keywords: virtue ethics, upbringing, reasons for action, Thomas Nagel, ethical pluralism 